\title{
DRY EYE DISEASE TERKAIT PENGGUNAAN VIDEO DISPLAY TERMINALS PADA PEKERJA ERA PANDEMI COVID-19
}

\section{Irfani Halimah Bharata}

Universitas Mataram, Indonesia

Email: irfanibharata@gmail.com

\begin{abstract}
Abstrak
Penyakit mata kering adalah penyakit multifactorial progresif pada permukaan okular yang ditandai oleh ketidakstabilan dan hiperosmolaritas tear film prekorneal. Gejala okular yang dirasakan penderita DED bervariasi dari ringan hingga berat dan dapat membawa dampak negatif pada kualitas hidup. Prevalensi DED pada pengguna video display terminals (VDT) mengalami peningkatan terutama pada masa pandemi COVID-19. Beberapa studi sudah membuktikan adanya hubungan antara DED dan penggunaan VDT. Beberapa hipotesis yang sering dikemukakan yang berkaitan dengan penurunan frekuensi mengedip komplit, hipofungsi kelenjar lakrimal, disfungsi kelenjar Meibomian, stres oksidatif dan inflamasi, serta fototoksisitas sinar biru. Beberapa tindakan intervensi dan pencegahan dapat dilakukan untuk mengurangi gejala DED pada pengguna VDT.
\end{abstract}

Kata Kunci: mata kering, video display terminals, tear film, permukaan okular

\begin{abstract}
Dry eye disease (DED) is a multifactorial progressive disease of ocular surface characterized by tear film instability and hyperosmolarity of the precorneal tear film. Patients with DED may experience range of ocular disturbances that may negatively impact their quality of life. The prevalence of DED is increasing among people who work with video display terminals (VDT), especially during the COVID-19 era. Studies have shown the association between DED symptoms and VDT usage. Complete blinking reduction, lacrimal gland hypofunction, Meibomian gland dysfunction, oxidative stress and local inflammation, and blue light phototoxicity are commonly accepted hypothesis. Several approaches are exist to treat and prevent DED among VDT workers.
\end{abstract}

Keyword: Dry eye, video display terminals, tear film, ocular surface

Diserahkan: 03-01-2022Ｄiterima: 25-01-2022Ｄiterbitkan: 20-02-2022

\section{Pendahuluan}

Dry eye disease (DED), disebut juga keratokonjungtivitis sicca, adalah penyakit kompleks, multifaktorial, dan progresif pada permukaan okular yang ditandai oleh ketidakstabilan tear film dan hiperosmolaritas yang membentuk sebuah lingkaran setan. DED merupakan penyakit mata yang umum dijumpai dalam praktik klinis. Prevalensi DED bervariasi dari 5\%-50\% dengan kecenderungan mengalami peningkatan seiring usia. Penderita DED seringkali mengeluhkan gejala seperti mata terasa kering, berat, 
kasar, terbakar, lelah, kemerahan, sensasi terdapat benda asing, dan peningkatan lakrimasi. Gejala-gejala DED seringkali memengaruhi kualitas hidup dan kondisi psikologis penderitanya (Craig et al., 2017).

Beberapa faktor risiko intrinsik yang berhubungan dengan onset dan eksaserbasi DED di antaranya usia lanjut, jenis kelamin perempuan, perubahan hormonal saat menopause, ras Asia Timur, penyakit autoimun (sindrom Sjögren), dan alergi. Sementara itu, faktor ekstrinsik seperti penggunaan obat-obatan topikal dan sistemik, penggunaan lensa kontak, rendahnya higienitas komposisi dan pengaplikasian kosmetik mata, rendahnya humiditas lingkungan, dan penggunaan air conditioning (AC) juga menjadi pemicu insiden dan eksaserbasi gejala DED (Barabino, 2021; Craig et al., 2017; Wang, Wei, \& Deng, 2021).

Salah satu faktor risiko ekstrinsik DED yang sedang meningkat prevalensinya adalah penggunaan video display terminals (VDT). VDT dalam istilah umum merujuk pada layar komputer, laptop, tablet, atau smartphone yang memproyeksikan informasi berupa tulisan dan gambar pada penggunanya. Pada era pandemi COVID-19 yang mengharuskan orang untuk bekerja, belajar, dan bersosialisasi dari rumah, peningkatan penggunaan VDT menjadi fenomena yang tidak dapat (Barabino, 2021; Wang et al., 2021).

Sebuah studi di China menunjukkan adanya peningkatan prevalensi DED pada pengguna VDT hingga mencapai 40.3\% (Hu, Zhu, Pan, Yang, \& Xiao, 2021). Tinjauan pustaka ini akan fokus membahas mengenai hubungan kejadian penyakit mata kering dengan penggunaan VDT, mekanisme yang melatarbelakangi fenomena tersebut, dan tindakan yang dapat mencegah maupun mengurangi keluhan mata kering pada penggunanya.

\section{Metode Penelitian}

Pencarian jurnal maupun artikel dengan topik terkait penyakit mata kering dan penggunaan VDT dilakukan melalui portal online ResearchGate (https://www.researchgate.net) dan PubMed (https://pubmed.ncbi.nlm.nih.gov). Kata kunci yang digunakan di antaranya "dry eye", "video display terminal", dan "computer display" dalam berbagai kombinasi. Artikel yang diinklusi adalah artikel yang memuat informasi mengenai hubungan penyakit mata kering dan penggunaan VDT dan intervensi yang dapat dilakukan. Artikel-artikel yang terbit dalam 5 tahun terakhir diutamakan untuk ditinjau. Selain itu, dilakukan pula peninjauan referensi yang digunakan oleh artikel-artikel yang diinklusi.

\section{Hasil dan Pembahasan}

\section{Fisiologi Tear Film Prekorneal}

Tear film prekorneal merupakan salah satu kompartemen media refraktif paling depan pada mata yang berfungsi memfokuskan bayangan visual di atas retina. Tear film memiliki ketebalan sekitar $3 \mu \mathrm{m}$ yang berada tepat di atas konjungtiva dan kornea. Tear film sendiri memiliki 3 lapisan terpisah, yaitu lapisan mukus (lapisan dalam), lapisan 
aqueous (lapisan tengah), dan lapisan lipid (lapisan luar). Lapisan mukus adalah lapisan tertipis dan terletak paling dalam. Musin yang membentuk lapisan ini disekresi oleh sel goblet konjungtival dan kelenjar Manz. Musin berperan untuk mengubah sifat hidrofobik kornea dan konjungtiva menjadi hidrofilik sehingga dapat dibasahi oleh air mata dan menjaga kestabilan air mata. Lapisan aqueous adalah lapisan yang membentuk sebagian besar volume tear film. Kelenjar lakrimal utama berperan dalam mensekresi komponen lakrimal pada lapisan ini. Kelenjar lakrimal aksesoris juga mensekresi air mata dalam jumlah jauh lebih kecil. Selain sebagian besar dibentuk oleh air, sejumlah kecil natrium klorida, glukosa, urea, dan protein juga terdapat dalam lapisan ini. Beberapa enzim seperti lisozim, laktoferin, dan betalisin juga terkandung dalam air mata. Lapisan lipid merupakan lapisan yang terletak paling luar dari tear film dan terdiri dari lapisan dalam tebal yang kaya molekul lipid polar dan asam lemak rantai panjang serta lapisan superfisial yang terdiri dari lipid non-polar. Lapisan ini memiliki fungsi paling penting dalam menjaga kestabilan tear film, yaitu mencegah terjadinya evaporasi berlebih dari air mata dan melumasi kelopak mata saat berkedip. Meibum, yang merupakan komponen utama lapisan lipid disekresi oleh kelenjar Meibomian konjungtival (Clayton, 2018).

Untuk mempertahankan kualitas penglihatan, tear film harus selalu dicegah dari kekeringan yang dapat merusak kestabilan permukaan okular. Berbagai mekanisme berperan dalam menjaga homeostasis tear film. Dua mekanisme utamanya adalah melalui gerakan mengedip (blinking) dan sekresi air mata oleh kelenjar lakrimal. Selain itu, air mata juga disekresikan oleh sel goblet dan kelenjar Meibomian. Instabilitas permukaan okular akibat evaporasi air mata berlebih dicegah melalui mekanisme homeostatik yang meregulasi sekresi dan distribusi air mata berdasarkan sinyal yang berasal dari permukaan okular (Bron et al., 2017; Nakamura, 2018).

\section{Patogenesis Umum Dry Eye Disease}




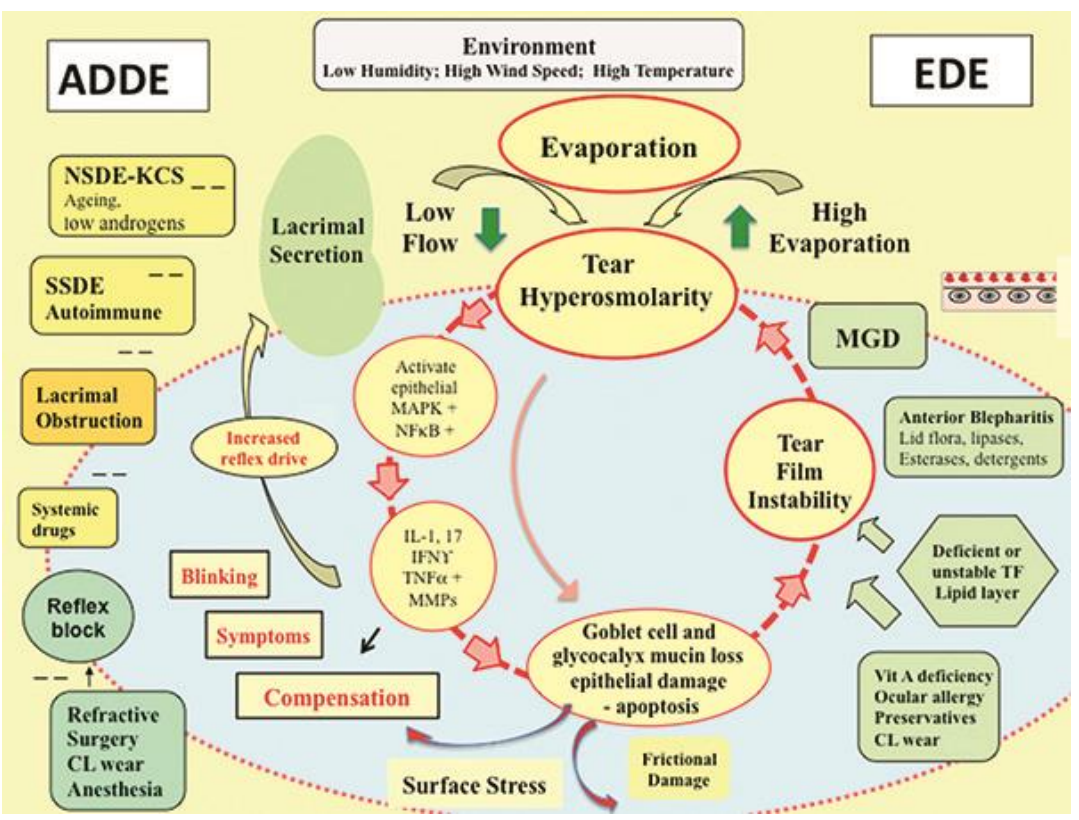

Gambar 1 Lingkaran Setan Dalam Patogenesis DED (Bron et al., 2017)

Pada DED, kegagalan dari mekanisme homeostatik tear film akan mengakibatkan defisiensi volume air mata karena produksi air mata yang tidak adekuat (aqueous deficient dry eye) dan/atau penurunan kualitas air mata akibat disfungsi kelenjar meibomian (evaporative dry eye). Kedua hal tersebut akan memicu instabilitas tear film, stres hiperosmolar, peningkatan friksi, dan iritasi mekanik pada permukaan okular. Ketidakstabilan dan hiperosmolaritas tear film bersama-sama membentuk sebuah lingkaran setan dalam patogenesis DED. Keadaan hiperosmolaritas menyebabkan rusaknya epitel permukaan okular akibat apoptosis, menurunnya jumlah sel goblet, dan disregulasi musin. Kerusakan pada epitel permukaan okular akan memicu aktivasi kaskade mediator inflamatorik dan pelepasan mediator-mediator inflamasi yang akhirnya akan memicu ketidakstabilan dari tear film. Di sisi lain, ketidakstabilan tear film yang terjadi akan semakin memperparah kondisi hiperosmolaritas yang sudah terjadi sebelumnya. Ketidakstabilan tear film tanpa didahului hiperosmolaritas dapat terjadi pada penderita xeroftalmia, alergi, penggunaan obat topikal, dan akibat pemakaian lensa kontak (Bron et al., 2017).

\section{Hubungan Penggunaan Visual Display Terminals dengan Penurunan Frekuensi Mengedip Komplit}

Mengedip (blinking) merupakan gerakan yang penting dalam mempertahankan kesehatan permukaan okular, drainase tear film, dan fungsi penglihatan. Mengedip juga menjadi fungsi esensial dalam mendistribusikan lapisan lipid serta memicu pelepasan sekresi minyak secara mekanik dari kelenjar Meibomian (Yamaguchi, 2018). Normalnya, sekitar $80 \%$ kedipan terjadi secara komplit dimana palpebra superior menutupi lebih dari dua per tiga luas kornea. Sementara itu, sekitar $18 \%$ kedipan dapat terjadi secara inkomplit dan $2 \%$ sisanya merupakan kedutan belaka (twitching) (Mineshita et al., 2021). 
Pada pengguna VDT, terjadi peningkatan atensi kognitif terhadap tugas visual selama bekerja yang memicu penurunan frekuensi kedipan komplit dan peningkatan jumlah kedipan inkomplit atau disebut juga dengan "flurries". Peningkatan jumlah kedipan inkomplit akan menyebabkan peningkatan evaporasi air mata dan daya akomodatif mata. Hal ini menyebabkan iritasi, kekeringan, dan rasa nyeri pada permukaan ocular (Jaiswal et al., 2019; Kim, Lim, Gu, \& Park, 2017; Parihar et al., 2016).

\section{Hipofungsi kelenjar lakrimal}

Penurunan frekuensi mengedip komplit pada pengguna VDT ditemukan konsisten bersamaan dengan penurunan sekresi air mata. Hal ini disebabkan karena sekresi dan distribusi air mata oleh kelenjar lakrimal diregulasi secara kontinyu oleh sinyal saraf sensorik dari kornea dan konjungtiva yang berperan dalam proses mengedip. Pada sebuah studi yang menganalisis patologis kelenjar lakrimal tikus coba, ditemukan adanya bukti penurunan jumlah dan hipertrofi dari sel acinar, hipertrofi dan akumulasi vesikel sekretorik dalam sitoplasma, serta hilangnya struktur intraselular sel. Gambaran ini merupakan karakteristik dari disfungsi sekrerotik pada kelenjar lakrimal sehingga hipofungsi kelenjar lakrimal merupakan salah satu hipotesis patogenesis DED yang berkaitan dengan penggunaan VDT (Nakamura, 2018).

\section{Disfungsi kelenjar Meibomian}

Disfungsi kelenjar Meibomian adalah abnormalitas kelenjar Meibomian kronik difus yang ditandai dengan obstruksi duktus terminalis atau perubahan kuantitatif atau kualitatif dari sekresinya, yaitu meibum. Meibum merupakan komponen lapisan lipid dari tear film yang penting untuk mencegah evaporasi air mata. Penipisan lapisan lipid akibat disfungi kelenjar Meibomian memicu timbulnya gejala iritasi dan inflamasi okular (Arita, Fukuoka, \& Morishige, 2017). Hal ini didukung oleh sebuah studi yang menyebutkan bahwa penggunaan VDT lebih dari 4 jam per hari berkaitan dengan disfungi kelenjar Meibomian yang ditandai oleh abnormalitas kelopak mata, hipoeksresi meibum, dan atrofi kelenjar Meibomian (Parihar et al., 2016).

\section{Disfungsi sel goblet}

Pada keadaan normal, MUC5AC akan disekresi oleh sel goblet konjungtival sebagai salah satu komponen dari tear film. Pada sebuah studi yang meneliti konsentrasi mucin pada tear film pengguna VDT, diketahui bahwa individu dengan rata-rata lama penggunaan VDT di atas 5 jam memiliki konsentrasi mucin 5AC (MUC5AC) yang lebih rendah daripada orang normal. Hal ini dapat dijelaskan karena penggunaan VDT akan memengaruhi kesehatan sel goblet konjungtival sehingga menurunkan produksi mucin pada permukaan okular. Hal ini akan berujung pada penipisan tear film dan kekeringan permukaan okular (Uchino et al., 2014)

\section{Stres oksidatif dan inflamasi permukaan okular}

Selain diperankan oleh tear film, proteksi dan viabilitas permukaan ocular juga dipengaruhi oleh berbagai sitokin, kemokin, neuropeptida, dan neurotropin seperti nerve growth factor (NGF). NGF memiliki sifat pleiotropik yang dapat mendukung regenerasi saraf perifer, meningkatkan sensitivitas korneal, meningkatkan densitas sel goblet 
konjungtival dan produksi mucin, serta meningkatkan produksi air mata. Pada penderita DED terkait VDT, ditemukan adanya peningkatan level sitokin proinflamatorik yaitu interleukin (IL)-1 $\beta$, IL-6, IL-10, interferon- $\gamma$, matrix metalloproteinase (MMP), dan tumor necrosis factor (TNF)- $\alpha$ (Nakamura, 2018; Yamaguchi, 2018). Penggunaan VDT juga dikaitkan dengan peningkatan ekspresi inducible nitrit oxide synthase (iNOS) yang merupakan sitokin proinflamatorik dan neurotoksik. Nitrit oksida radikal yang disintesis iNOS akan memicu stres oksidatif dan inflamasi pada permukaan okular (Labetoulle et al., 2019; Nakamura, 2018). Pada penderita DED, peningkatan level NGF pada permukaan okular akan terjadi sebagai mekanisme kompensatorik (Cortes et al., 2018; Mehra \& Galor, 2020).

\section{Fototoksisitas blue light}

Pada umumnya, perangkat VDT akan memancarkan amplitudo emisi cahaya puncak yang disebut "white-light LEDs" dengan panjang gelombang 400-490 nm. Blue light atau sinar biru yang merupakan spektrum cahaya kasatmata berenergi tinggi termasuk di dalam rentang ini (400-450 nm) (Tosini, Ferguson, \& Tsubota, 2016). Fototoksisitas blue light yang berasal dari layar light emitting diode (LED) pada perangkat VDT ternyata juga dapat menjadi pemicu terjadinya DED. Sebuah studi menemukan bahwa blue light dengan panjang gelombang rendah $(410-480 \mathrm{~nm})$ secara signifikan menurunkan aktivitas mitotik, viabilitas selular, dan meningkatkan produksi spesies oksigen reaktif lokal (anion superoksida, hidrogen peroksida, dan radikal hidroksil). Hal ini memicu stres oksidatif pada epitelium korneal yang bermanifestasi sebagai gejala DED (Lee et al., 2014; Niwano, Kanno, Iwasawa, Ayaki, \& Tsubota, 2014). Selain itu, sinar LED juga memicu kelelahan mata (eye fatigue) dan kerusakan retinal yang ditandai dengan degenerasi fotoreseptor yang berujung pada aktivasi kaspase apoptosis, nekroptosis, dan nekrosis (Jaadane et al., 2015; Tosini et al., 2016).

\section{Intervensi dan Pencegahan Dry Eye Disease Terkait Penggunaan Video Display Terminals}

Pembatasan screen time atau waktu tatap layar merupakan intervensi utama yang disarankan pada penderita DED terkait penggunaan VDT. Istirahat selama 15 menit setiap 2 jam penggunaan VDT merupakan saran yang paling sering direkomendasikan. Istirahat dengan rumus "20-20-20 Rule" juga dapat diterapkan, dimana setiap 20 menit penggunaan VDT disarankan untuk mengalihkan fokus mata kepada objek yang berjarak 20 kaki (6 meter) selama 20 detik (American Academy of Ophthalmology, 2019). Modifikasi gaya hidup dengan menjaga jarak pandang terhadap layar VDT ( 90 $\mathrm{cm})$ dengan sudut pandang ke bawah $\left(10^{\circ}\right)$ juga dapat membantu memperbaiki keluhan DED. Penambahan pelembab ruangan (humidifier) di samping perangkat VDT dan latihan mengedip (menutup mata selama 2 detik, lalu membuka mata, lalu menutup mata lagi selama 2 detik dan memijat mata yang tertutup selama 2 detik) juga dapat membantu mencegah DED pada pengguna VDT (Kim et al., 2017; Parihar et al., 2016).

Penggunaan tetes mata sebagai air mata buatan (artificial tears) dapat membantu meredakan gejala DED dan meningkatkan frekuensi kedipan secara signifikan, tetapi tidak menyelesaikan masalah yang mendasarinya. Beberapa jenis antioksidan seperti 
polifenol dan asam lemak omega-3 diketahui memiliki efek antiinflamatorik dan antioksidan yang dapat membantu memperbaiki tear film serta epitelium kornea sehingga dapat mengurangi keluhan pada DED (Lee et al., 2014). Berbagai hasil alam yang memiliki potensi antiinflamatorik dan antioksidan juga mulai banyak dikembangkan sebagai terapi DED, contohnya royal jelly yang memiliki efek amelioratif terhadap gejala DED dan diketahui mampu memperbaiki kapasitas sekresi air mata pada tikus coba (Nakamura, 2018).

\section{Kesimpulan}

Kejadian DED atau mata kering pada pengguna VDT berkaitan dengan penurunan frekuensi mengedip komplit, hipofungsi kelenjar lakrimal, disfungsi kelenjar Meibomian, stres oksidatif dan inflamasi permukaan okular, serta fototoksisitas sinar biru. Peningkatan penggunaan VDT berkaitan dengan peningkatan progresivitas gejalagejala DED. Intervensi dan tindakan preventif yang tepat perlu diberikan untuk meminimalisasi dampak negatif DED terhadap kesehatan okular dan kualitas hidup penderitanya. 


\section{BIBLIOGRAFI}

Arita, Reiko, Fukuoka, Shima, \& Morishige, Naoyuki. (2017). New insights into the morphology and function of meibomian glands. Experimental Eye Research, 163, 64-71. Google Scholar

Barabino, Stefano. (2021). A Narrative Review of Current Understanding and Classification of Dry Eye Disease with New Insights on the Impact of Dry Eye during the COVID-19 Pandemic. Ophthalmology and Therapy, 10(3), 495-507. Google Scholar

Bron, Anthony J., de Paiva, Cintia S., Chauhan, Sunil K., Bonini, Stefano, Gabison, Eric E., Jain, Sandeep, Knop, Erich, Markoulli, Maria, Ogawa, Yoko, Perez, Victor, Uchino, Yuichi, Yokoi, Norihiko, Zoukhri, Driss, \& Sullivan, David A. (2017). TFOS DEWS II pathophysiology report. Ocular Surface, 15(3), 438-510. Google Scholar

Clayton, JA. (2018). Dry eye. New England Journal of Medicine, 378(23), 2212-2223. Google Scholar

Cortes, Magdalena, Esposito, Graziana, Sacco, Roberto, Gillet, Véronique Bernadette, Ianni, Andrea, \& Micera, Alessandra. (2018). NGF and iNOS Changes in Tears from Video Display Terminal Workers. Current Eye Research, 43(9), 1119-1125. Google Scholar

Craig, Jennifer P., Nichols, Kelly K., Akpek, Esen K., Caffery, Barbara, Dua, Harminder S., Joo, Choun Ki, Liu, Zuguo, Nelson, J. Daniel, Nichols, Jason J., Tsubota, Kazuo, \& Stapleton, Fiona. (2017). TFOS DEWS II Definition and Classification Report. The Ocular Surface, 15(3), 276-283. Google Scholar

Hu, Jing Wen, Zhu, Xiu Ping, Pan, Shi Yin, Yang, Hua, \& Xiao, Xiang Hua. (2021). Prevalence and risk factors of dry eye disease in young and middle-aged office employee: A Xi'an study. International Journal of Ophthalmology, 14(4), 567573. Google Scholar

Jaiswal, Sukanya, Asper, Lisa, Long, Jennifer, Lee, Abigail, Harrison, Kirsten, \& Golebiowski, Blanka. (2019). Ocular and visual discomfort associated with smartphones, tablets and computers: what we do and do not know. Clinical and Experimental Optometry, 102(5), 463-477. Google Scholar

Kim, Dong Ju, Lim, Chi Yeon, Gu, Namyi, \& Park, Choul Yong. (2017). Visual Fatigue Induced by Viewing a Tablet Computer with a High-resolution Display. Korean Journal of Ophthalmology, 31(5), 388. Google Scholar

Labetoulle, Marc, Baudouin, Christophe, Calonge, Margarita, Merayo-Lloves, Jesús, Boboridis, Kostas G., Akova, Yonca A., Aragona, Pasquale, Geerling, Gerd, Messmer, Elisabeth M., \& Benítez-del-Castillo, José. (2019). Role of corneal nerves in ocular surface homeostasis and disease. Acta Ophthalmologica, 97(2), 137-145. Google Scholar

Lee, Jee Bum, Kim, Soo Hyun, Lee, Seung Chul, Kim, Hee Gu, Ahn, Ho Geun, Li, 
Zhengri, \& Yoon, Kyung Chul. (2014). Blue light-induced oxidative stress in human corneal epithelial cells: Protective effects of ethanol extracts of various medicinal plant mixtures. Investigative Ophthalmology and Visual Science, 55(7), 4119-4127. Google Scholar

Mehra, Divy, \& Galor, Anat. (2020). Digital screen use and dry eye: A review. AsiaPacific Journal of Ophthalmology, 9(6), 491-497. Google Scholar

Mineshita, Yui, Kim, Hyeon Ki, Chijiki, Hanako, Nanba, Takuya, Shinto, Takae, Furuhashi, Shota, Oneda, Satoshi, Kuwahara, Mai, Suwama, Anzu, \& Shibata, Shigenobu. (2021). Screen time duration and timing: effects on obesity, physical activity, dry eyes, and learning ability in elementary school children. BMC Public Health, 21(1), 1-11. Google Scholar

Nakamura, Shigeru. (2018). Approach to dry eye in video display terminal workers (Basic science). Investigative Ophthalmology and Visual Science, 59(14 Special Issue), DES130-DES137. Google Scholar

Niwano, Yoshimi, Kanno, Taro, Iwasawa, Atsuo, Ayaki, Masahiko, \& Tsubota, Kazuo. (2014, July). Blue light injures corneal epithelial cells in the mitotic phase in vitro. The British Journal of Ophthalmology, Vol. 98, pp. 990-992. Google Scholar

Parihar, J. K. S., Jain, Vaibhav Kumar, Chaturvedi, Piyush, Kaushik, Jaya, Jain, Gunjan, \& Parihar, Ashwini K. S. (2016). Computer and visual display terminals (VDT) vision syndrome (CVDTS). Medical Journal Armed Forces India, 72(3), 270-276. Google Scholar

Tosini, Gianluca, Ferguson, Ian, \& Tsubota, Kazuo. (2016). Effects of blue light on the circadian system and eye physiology. Molecular Vision, 22(August 2015), 61-72. Google Scholar

Wang, Lixiang, Wei, Xin, \& Deng, Yingping. (2021). Computer Vision Syndrome During SARS-CoV-2 Outbreak in University Students: A Comparison Between Online Courses and Classroom Lectures. Frontiers in Public Health, 9(July), 1-7. Google Scholar

Yamaguchi, Takefumi. (2018). Inflammatory response in dry eye. Investigative Ophthalmology and Visual Science, 59(14 Special Issue), DES192-DES199. Google Scholar

First publication right:

Jurnal Syntax Fusion: Jurnal Nasional Indonesia

This article is licensed under:

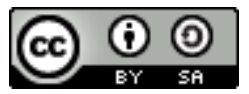

